Restorative Justice

\title{
Theo Gavrielides, Waves of healing: using restorative justice for street group violence
}

\author{
Ian D. Marder
}

To cite this article: Ian D. Marder (2014) Theo Gavrielides, Waves of healing: using restorative justice for street group violence, Restorative Justice, 2:1, 103-106, DOI: 10.5235/20504721.2.1.103

To link to this article: https://doi.org/10.5235/20504721.2.1.103

曲 Published online: 07 May 2015.

Submit your article to this journal ๘

山 Article views: 25

View Crossmark data \lceil 


\section{Theo Gavrielides, Waves of healing: using restorative justice for street group violence. London: Independent Academic Research Studies (IARS) Publications, 2012, 72pp., ISBN: 978-1907641107.}

Researchers and proponents of restorative justice often look to apply its values, processes and practices to some of the many crime problems that remain largely unexplored in a restorative context. Following his earlier publications on the use of restorative justice with hate crime, violence against women and clergy child sex abuse, Gavrielides once again contributes to these efforts by investigating the use of restorative justice as a response to street group violence, which he defines as street violence involving 'five or more people acting in concert' and which is 'unilateral, time-bound and non-governmental' (16). In order to achieve this, he looks at four case studies, each of which involves one or more instances of street group violence of the type defined above: riots in several English cities in August 2011; violence between Muslim and Hindu communities in India in December 1992 and February 2002; post-hockey riots in Vancouver, Canada, in June 2011; and anti-austerity protests in Greece from 2010 to 2012. For each, he describes the nature of the violence and investigates through a review of the literature and interviews whether there were any national or localised attempts to respond restoratively.

The book touches on both the conceptual and practical issues with using restorative justice to respond to this type of disorder, and the author does well to combine policy and legislative analysis with the relevant theoretical debates in such a short space. Moreover, to his credit, Gavrielides is very explicit about what can and cannot be inferred from his findings and interpretations. He acknowledges that this research is merely a first step towards understanding how restorative justice might be applicable in this context, while noting that 'its conclusions should not be taken as universal truths' (10). Certainly, we are unable to generalise from the small amount of qualitative data collected, and, as Gavrielides himself mentions, there are several methodological limitations when using case studies in social research. Still, this should not serve to prevent the text from fulfilling its stated aim — to 'spark a new debate in this grey area of policy and practice' (9).

The author affirms the study's importance with reference to its divergence from the existing literature on the use of restorative justice with inter-personal, rather than group, incidents of violence. Essentially, Gavrielides is contending here that policy and research are justified in treating group and individual violence as distinct issues on the basis of significant differences in their nature and dynamic. This seems to be a reasonable assertion-the separate treatment of these issues in research might help us to develop more practical and nuanced responses to each-and I would hasten to add that many more distinct crime problems are inaccurately conflated by an unresponsive justice process, such as young adult and adult offending. 
For each case study, the author explains the context in which the disorder occurred, the nature and scope of the violence and the extent of the harm caused, as well as offering a broad outline of the reactions and responses of elected officials, criminal justice agencies and civil society organisations. He notes that governments typically responded with retributive rhetoric and criminal justice organs focused on the imposition of punitive sanctions on offenders, though there were some individuals in each of these two groups, as well as many in civil society, who publicly lobbied for, or experimented with, a restorative or victim-centred approach. For instance, while the BBC reported that, by August 2012, 1,292 individuals had been jailed following their involvement in the English riots of 2011, receiving an average sentence of 16.8 months, there were also many localised attempts to use restorative justice with rioters and their victims, exemplified by the restorative interventions offered by Greater Manchester Probation Trust, Lambeth and Croydon Youth Offending Teams and a partnership in Southwark between the Metropolitan Police, the local authority and a variety of charities and community groups.

Gavrielides also describes a restorative project in Gujarat, India, initiated following widespread violence between Muslim and Hindu communities in 2002. Known as the Gujarat Harmony Project, it was set up by a collaboration of NGOs, development agencies and civil society, bringing together rioters and victims from both sides of the conflict. In terms of the two remaining case studies, Vancouver and Greece did not, at the time the research was conducted, have any specific restorative projects in place to respond to their riots of 2011 and 2010-2012 respectively, though Gavrielides did discover that a restorative-natured community forum had been held in the former by a nearby parish group. Indeed, the Vancouver riots do offer an interesting case study, particularly given that Canada has a comparatively long history of using restorative justice in the criminal justice process, as well as a relatively conducive legislative infrastructure. Yet, as Gavrielides points out, efforts to respond restoratively were held back in this case by a lack of funding and the slow pace of the criminal justice process (although the provincial government has now agreed to invest in some pilot cases).

Given the claims of progress towards the integration of restorative justice into the Canadian criminal justice process in recent decades, the apparent lack of a coordinated, restorative response to the riots in Vancouver is quite curious indeed, and should serve as a warning to those of us in England and Wales and anywhere else with nascent restorative justice legislation. This experience seems to imply that, while a legislative underpinning might be an important step towards the integration of restorative justice into a nation's criminal justice process, its ability to use restorative practices in criminal cases also depends heavily on adequate levels of public investment and the cooperation of criminal justice agencies. On a similar note, it will be interesting to see how Sweden, which, like Canada, has long been seen as having a justice model less punitive than that of the Anglo-American (or Neo-Liberal) model, responds to its own recent incidences 
of riot in Stockholm, or, indeed, how the Burmese state and civil society will respond to recent street group violence involving Muslim and Buddhist communities.

Needless to say, Gavrielides, who has been an advocate of restorative justice for many years, concludes that it could and should be piloted as a response to street group violence: 'our analysis of the street group violence phenomenon suggests that its nature presents RJ with a unique opportunity to show its potential' (43). He notes that, in his experience, the extent of the shame exhibited by rioters is such that they might be particularly suitable for participation in a restorative intervention. Furthermore, in developing a model of restorative justice to be used in this context, ostentatiously styled as 'Waves of Healing', he identifies some of the main characteristics that a suitable restorative infrastructure would require. For example, he contends that the necessary foundations must exist outside of law and government so that restorative processes are not reliant on the state, though they should still be offered to both child and adult offenders by criminal justice agencies at the post-conviction and post-sentence stages. He also suggests that voluntariness, preparation, restoration of the victim and resettlement of the offender should be prioritised, while emphasising the need to evaluate any pilot using both quantitative and qualitative methodologies, with a view to analysing a broader range of outcomes than government research typically pursues.

This certainly is an important time for research and policy where street group violence is concerned, with many (if not most) countries exhibiting several of the risk factors necessary for such violence to occur: macroeconomic stagnation or decline, political instability, pockets of extreme and/or relative material deprivation and social exclusion, high levels of unemployment and youth unemployment, the rising influence of extreme political groups, and skyrocketing food prices. Indeed, as I write, street group violence has flared up between political factions in Greece following the assassination of Pavlos Fyssas, an anti-fascist rap artist, by supporters of the far-right organisation Golden Dawn. So, in a world desperate for conflict resolution and creative peace building, where does restorative justice fit in with instances of riot? Might there be scope for something more substantial than the small-scale use of restorative practices typically associated with street crime? As Gavrielides shrewdly observes, there are comparisons to be made between the implementation of restorative justice in the context of street group violence and its implementation in what might be termed the transitional justice context, as exemplified by the Truth and Reconciliation Commission in South Africa, or the Equity and Reconciliation Commission in Morocco. Both situations are usually characterised by mass human rights violations (in the former, by other individuals or groups; in the latter, by the machinery of the state). Moreover, due to the nature and extent of the harm done, there exists in both cases a blurred boundary between victim and community, where most members of an affected community, even if not directly materially or physically harmed by the actions of an offending party, might still feel that they are part of a community of victims. 
In the English example, it may be that some offenders and victims have since benefited from the restorative and quasi-restorative processes offered by criminal justice agencies, such as referral orders, or from localised schemes offered in prisons or by probation. Yet, were those riots not momentous enough to justify a transitional justice process? It certainly seems possible that such a process could contribute towards efforts to reconcile communities, reintegrate offenders back into society, heal victims and re-establish social harmony. I personally believe that there is much to learn from the truth-telling, victim vindication and stakeholder participation aspects of transitional justice models, and that large-scale, inter-community dialogue could be used to complement locally delivered restorative interventions in cases of street group violence. At present, however, as Gavrielides states, our restorative infrastructure is overly reliant on criminal justice agencies and state mechanisms, meaning that a broader public debate on the use of restorative justice in this context cannot come soon enough.

Ian D. Marder

University of Leeds,UK,lw08im@leeds.ac.uk 